\title{
The Canaanite woman's request or about prayers as forms of linguistic politeness ${ }^{\dagger}$
}

\author{
Daiana Felecan* \\ Faculty of Letters, Technical University of Cluj-Napoca, North University Centre, Str. Victoriei 76, 430122 Baia Mare, Romania
}

\section{Article info}

History:

Received May 27, 2018

Accepted June 9, 2018

Published October 7, 2018

Key words:

stylistics

biblical text

philology

ethnolinguistics

rhetoric

\begin{abstract}
The paper aims to establish the semantic boundaries between the terms prayer and request, and implicitly the pragmatic meanings actualized by the two lexemes on different levels of language. Through prayers, a sender conveys a message to a referentially indeterminate receiver in the pragmatic context of the phenomenal world, but "identifiable" exclusively in the world of necessities. The author will adduce as an example a dialogue between the representatives of two spiritually delimited spaces (the Canaanite woman and Jesus Christ). The woman asks for her own mercy with the purpose of exorcising her daughter's evil spirits. Due to the skilfulness with which she negotiates meanings while observing situation roles, the woman proves to be a good practitioner of the cooperative principle, in general, and of pragmatic politeness, in particular. The locutor uses devices to support the most appropriate discourse strategies which would lead her to obtain an optimum level of communication - more precisely, to accomplish the aim of her prayer: her daughter's recovery.
\end{abstract}

\section{Aims, specificity, lexical-semantic categorization and thematic roles}

1.1. Prayer is the (verbal) result of an intense experience of an attitude or psycho-emotional state. The extent and strength of this experience is different for every subject considered as an individuality and as a member of a community who observes certain customs. It is known that ethnolinguistic civilisations (and within them speakers adhering to various religious beliefs) manifest specific psychological behaviours in the management of religious experience, and the varied range of particular feelings and attitudes triggers diverse linguistic reactions. Thus, pragmatic meanings conveyed by language elements on various levels are encoded distinctly (not only across different languages, but also across functional variants of a language).

This paper aims at recording the discursive manifestations identified in the prayer from the gospel pericope about the Canaanite woman. The theoretical frameworks employed pertain to pragmalinguistics, stylistics, functional grammar and theology.

1.2. Of the lexicographical entries for the term rugăciune ('prayer'), the following acceptations are taken into account: "a personal attempt at establishing a direct contact with the divinity; request, gratitude or

${ }^{\dagger}$ Further remarks on the linguistic act of praying in contemporary Romanian and a tentative taxonomy of this subtype of religious discourse are found in the presentation on Construction and interpretation in prayers, delivered on the occasion of the Ninth National Conference "Religious Text and Discourse", Rodna, Romania, May 10-12, 2018. The paper will be published in the proceedings of the aforementioned scientific event.

*Email address: daianal8felecan@yahoo.com.

${ }^{1}$ Rugăciune < lat. rogationem (rogatio, -onis (f.) ( « demande, proposition de loi ») < rogo (1) « demander, prier, soliciter » (Bréal \& Bailly, 1886, p. 311). «Rogo était le terme consacré pour proposer une loi au peuple. De là, le sens des nombreux dérivés et composés [...] » (Ibidem, p. 311).

A ruga ('to pray') "1. Transitive verb. To demand someone the fulfilment of a wish, favour, act of assistance etc. [...] 2. Reflexive verb. (In religious activities) To say a prayer, to invoke the divinity” (bttps://dexonline.ro/definitie/ruga). 
praise addressed by believers to the divinity"; "humble request; imploration for divine grace"; "humble entreaty to God"; "[...] a symbol of one's confession of faith, love, hope and dependence unto God" 2

As one can notice, the definition restricts the possibilities for the semantic manifestation of the referent to one, which belongs to the sphere of religion (the supreme divinity, the Holy Virgin, other saints and angels).

As opposed to rugăciune ('prayer'), rugăminte ('request') is a "(persistent) demand addressed to someone [my italics] to obtain something"; "polite request (addressed to a person) [my italics] to do a service or to fulfil a wish" (bttps://dexonline.ro/definitie/rug\%C4\%83minte, originally Romanian). The meanings recorded in the dictionary for the term rugăminte ('request') leave the thematic role of the Target referentially empty, as opposed to what happens in the case of the other term. The vague (indeterminate and semantically incomplete ${ }^{3}$ ) identification-expressed by means of an existential quantifier (cuiva 'to someone') - shifts the focus from the previous receiver (the divinity) to one that is, according to its name, countable (interchangeable ${ }^{4}$ ) as human beings.

The lack of referential overlapping (divinity vs. human) renders it impossible to use the two lexemes in contexts of complete semantic-referential equivalence. Implicitly, these terms are not perfect synonyms from the viewpoint of pragmatics when considered as arguments (Agent vs. Beneficiary) (see Fillmore's (1977) perspective on the grammar of cases).

1.3. In the case of prayers, senders pertain to a pragmatic context from the world of necessity, whereas in the case of requests, the senders' existence can be determined under the influence of the human senses.

A distinction can be made between:

- active, de iure participation of churchgoers to a sermon (observing the proper ritual script - kneeling, making the sign of the Holy Cross, kissing the icons and vestments) and

- de facto participation, manifested in the reading (out loud or in one's mind)/envisaging a prayer in another space than that officially associated with the religious ritual.

In the former case, the actualization of the inventory of nonverbal elements constitutive of a religious sermon occurs under the "guardianship" of a representative of the clergy. The priest validates the aforementioned elements by practising the interaction/eucharist together with the audience as active enacters of the ritual gestures specific to a certain faith.

For those whose participation to the unfolding of a sermon is passive (for instance, at home, in front of the television), carrying out the nonverbal aspects, the "material cover" of the Holy Mass becomes optional (the respective actions are easily "overlooked" and can thus be eliminated; in the absence of a priest, individuals do not necessarily feel the obligation/appropriateness to kneel, as all the indications that refer to the modus function as stage directions that can be "sacrificed", if needs be, for practical reasons, such as reducing the time allotted to praying). In this way, the fulfilment of "technical" indications for one's religious behaviour, which forego or cross the unwinding path of a prayer, depends on a believer's (non-)imitative attitude. Praying is construed as:

- closely following the requirements imposed by the sacred text-and together with the other participants in the respective religious act, or as

- "violation" (i.e., personal choice) of the code of ritual gestures completing the actual utterance/raising of a prayer.

1.4. The lexical structure and the distribution of thematic roles in prayers as utterances in Romanian

\footnotetext{
${ }^{2}$ In Romanian, the term is seldom used as a synonym for rugăminte ('request'), insistență ('demand') and rugă ('plea'), as well as for the (religious) terms worship, reverence or the (archaic and regional) words ocinaș ('prayer', especially with reference to the Lord's Prayer), molitvă ('special prayer for the forgiveness of sins') and rugare ('prayer') (see https://dexonline.ro/definitie/rug\%C4\%83ciune, originally Romanian).

${ }^{3} \mathrm{~A}$ definite description is incomplete "when it fails to determine as its referent a unique world object" (Moeschler \& Reboul, 1999, p. 339, originally Romanian).

${ }^{4}$ The target may become itself the addresser of a request.
} 
observe the linguistic algorithm below:

Someone ${ }_{\text {[Agent] }}$ asks ${ }_{[\mathrm{verb}}$ something ${ }_{\text {[Theme] }}$ from someone (else) ${ }_{[\text {Target] }} \pm$ for someone ${ }_{\text {[Beneficiary] }}$ \pm purpose $[$ Argument]

Someone $=$ the (human) sender of the prayer;

To pray $=$ praying index;

- verb occurring in one of the grammatical forms (performative present tense of prayers) (I/we) pray to you (sg./pl.) or as a lexical and stylistic variant such as to listen, to ask, to give, to beg, to do and to mediate;

- transitive verb with a double object: in a ternary structure, a direct object co-occurs with a secondary object, both objects being required by the semantic-syntactic framework of the head of the phrase and expressing the aforementioned thematic roles:

- to ask something from someone (the order of the two objects is flexible; the fixed word order corresponds to the syntactic pattern of established prayers): from someone (prepositional object ${ }^{5}$ which announces the obligatory occurrence of the referent, indicated by various lexical-grammatical means: the vocative case of a proper name or personal pronoun, second-person singular form);

- verbum dicendi, introducing the direct speech (Te rog ajută-mă!', literally 'I pray you help me!') and realised as an imperative-hortative utterance.

Something $=$ secondary object, the (spiritual or material) object/content of a prayer, whose lexical-grammatical realization may consist of:

- the (imperative-desiderative) head of a verb phrase: the duration of the action designated by the meaning of the verb is not meant to have the same (momentary) "length" as the "performativity" of the praying index, but an extended validity whose beneficial effects would follow an individual throughout his/her earthly journey (Te rog izbăvește-mă de rău!, literally 'I pray to you protect me against evil!'), or

- the head of a noun phrase (Sfinte Antoane, mare făcător de minuni, roagă-te pentru noi!, literally 'Saint Anthony, great performer of miracles, pray for us!').

From someone $=$ the (divine) receiver of a prayer, the definite description (form of address): Doamne (Dumnezeule)! ('Lord (God)!'), Isuse (Christoase)! ('Jesus (Christ)!'), (Sfintă) Maria! ('(Holy) Mary!'), (Sfinte) Antoane! ('(Saint) Anthony!'), etc.

For someone $=$ the person for whose benefit the prayer is made (Roagă-te pentru noi / familia mea / cei răposați!, literally 'Pray for us/my family/the dead!', etc.).

With a certain purpose $=$ the reason for praying (why the prayer is made), whose explicit expression is optional.

\section{The Canaanite woman's request or on redeeming one's child from the sins of the parents}

By promoting piety and humbleness as main attitudes in communication, the prayer is one of the forms of manifestation, preservation and consolidation of linguistic politeness. To prove the way in which verbal politeness is achieved in this subtype of religious discourse, this paper discusses the Prayer of the Canaanite Woman.

\footnotetext{
${ }^{5}$ In the Romanian phrase a ruga ceva pe cineva ('to ask something from someone'), pe cineva (literally 'on' + 'someone') functions as a direct object.
} 
NIV, Matthew, 15, 21-28

Leaving that place, Jesus withdrew to the region of Tyre and Sidon.

A Canaanite woman from that vicinity came to him, crying out, "Lord, Son of David, have mercy on me! My daughter is demon-possessed and suffering terribly."

Jesus did not answer a word. So his disciples came to him and urged him, "Send her away, for she keeps crying out after us."

He answered, "I was sent only to the lost sheep of Israel."

The woman came and knelt before him. "Lord, help me!" she said.

He replied, "It is not right to take the children's bread and toss it to the dogs."

"Yes it is, Lord," she said. "Even the dogs eat the crumbs that fall from their master's table."

Then Jesus said to her, "Woman, you have great faith! Your request is granted." And her daughter was healed at that moment.

(https://www.biblegateway.com/passage/?search=Matthew+15 rversion=NIV)

2.1. For the meeting between the two locutors to occur, they first have to step outside (to disregard the jurisdiction of personal ethics), to become dislocated, each of them endangering the other's quality as devoted interpreter/practitioner of the Word of the God they worship.

"Leaving that place, Jesus withdrew", namely He abandoned the familiar land, governed by (Jewish) law, and entered geographical "parts" pertaining to different (i.e., pagan) laws. The Canaanite woman belongs to these new/yet untreaded realms (due to sacred interdictions), as pointed out by the spatial indication ("the region of Tyre and Sidon") and the specification of her ethnicity ("Canaanite"). Like Jesus, the woman leaves as well (she, too, departs from the space in which her law was in effect): "came to him, crying out".

The dialogue initiative is taken by the woman. Its first part consists of an expressive speech act in the indepth structure of the text, but with directive realisation at the surface of the text ("Have mercy on me!"): designating the Interlocutor by means of a generic appellative, Doamne ('Lord'), followed by a mediated nominal phrase identifying the unique referent (Mântuitorul 'Saviour'): Fiul lui David 'Son of David' (by evoking a well-known referent in view of underlining the Interlocutor's distinguished origin-a compliment made by bringing into discourse the onomastic marker that designates Jesus' paternal descent). In what follows, the aim of the woman's prayer is expressed explicitly: "My daughter is demon-possessed and suffering terribly."

In this first verbal intervention, the woman focuses her attention on the object of her plea ("Have mercy on me!"), but the presence of the form -mă ('me'), a first-person personal pronoun in the singular functioning as a direct object, constitutes a false lead in the identification of the real suppliant-for the time being, the latter's voice is "borrowed" by that of the woman uttering the prayer. Subsequently, the reader discovers in the absent person of the daughter the source of the utterance, the initial locutor-as it is called in the theory of linguistic polyphony-, the actual beseecher, whose message is conveyed by the mother due to the deterioration of the said subject's mental state.

Instead of a list that would describe the requests to be fulfilled by the Saviour for the woman's personal benefit, a single claim is made, whose object consists of showing her mercy. This action does not display a manifest connection-on the level of the verbal means of expression (argumentative connectors are absent) - with the real beneficiary (the daughter) of the effects that the activation of this feeling (mercy) would produce. According to the Canaanite woman's interpretation, receiving mercy would have as a result an improvement of her daughter's health (being forgiven for the sins of her parents ${ }^{6}$, especially

\footnotetext{
${ }^{6}$ To support the current interpretation, an episode from the Old Testament can be adduced, in which an example of ancestral curse is found: Noah curses Canaan, his grandson (Genesis, 9, 18-27):

The sons of Noab who came out of the ark were Shem, Ham and Japheth. (Ham was the father of Canaan.)

These were the three sons of Noah, and from them came the people who were scattered over the whole earth.

Noah, a man of the soil, proceeded to plant a vineyard.
} 
those of her mother). Thus, the mother takes the entire blame for the child's condition, having the faith that clearing her sins would eliminate her daughter's suffering.

Although a verbal reaction is naturally expected to the woman's request, the Saviour initially replies by means of silence, non-words, apparently ignoring and defying the woman's brave attitude. However, he eventually responds indirectly, employing the strategy of "declining jurisdiction", rather as a reaction to the disciples' insistence, who are revolted and puzzled by the Teacher's unusual attitude:

\section{Jesus did not answer a word. So his disciples came to him and urged him, "Send her away, for she keeps crying out after us." \\ He answered, "I was sent only to the lost sheep of Israel."}

The conversational implicature "I was sent only to the lost sheep of Israel", pragmatically decoded as "She is not a daughter of the people of Israel, she worships idols, therefore she is not my concern", contains the first explicit flaw (after the implicit one conveyed by the Interlocutor's silence), namely the violation $\mathrm{He}$ Himself commits by entering a foreign land, where one finds, as expected, "lost sheep" pertaining to other houses than that of Israel. Does this not seem to be a deliberate intrusion of the Saviour in other "houses" to test the faith professed and subsequently, depending on the result, to encourage its growth within those spaces?

Through the act of praying, the woman proves to have the courage to face the unknown (she had only heard about Him, she had not met Him); she displays resolution, tactfulness and polite behaviour, which are salient in each of her verbal enterprises.

Her kneeling before Jesus ("The woman came and knelt before him. 'Lord, help me!' she said.") is a nonverbal introduction to which she resorts strategically to win some of the Interlocutor's trust. Her gesture is followed by a new verbal expression of the supplicant prayer: "Lord, help me!". Somehow, this is the natural development of the stages of the prayer: the woman knew that, once her sins were forgiven/she was shown mercy, help would be granted for her need. That is why she moves from the semantically vague "have mercy on me" (vague because the woman does not confess the sins committed, but asks for overall grace, generally speaking) to the concrete "help me" with respect to the aforementioned cause.

It is for the first time that the Saviour replies to the woman. However, He does not use a marker of address, but a generic assessment which can be linked to several interpretative values (evaluative, deontic, prescriptive, advisory) on the pragmatic level: "He replied, 'It is not right to take the children's bread and toss it to the dogs."

Normally, such a (denigrating, slurring) deprecation (exhibiting the Locutor's unfavourable attitude) would have been enough to shatter anyone's faith, which was, to begin with, grounded in "hearsay". It was not the case with the Canaanite woman, who meekly receives and assumes the insulting name "dogs", which was used by the Jews to describe other people. Moreover, without riposting, she identifies with this appellation and employs it in discourse as a term for self-characterisation. Her acquiescence ("“Yes it is, Lord,' she said. 'Even the dogs eat the crumbs that fall from their master's table."') is indicative of accepting without protest the belief in the inferiority of one's people as opposed to the superiority which the chosen people had claimed for itself.

The last verbal intervention of the Saviour sheds light on His behaviour throughout the encounterHe postpones, delays the verdict (bestowing the grace of healing on the daughter) in order to offer attendants an instance of faith that is more treasured precisely because it was professed by an outsider. The

\footnotetext{
When he drank some of its wine, he became drunk and lay uncovered inside his tent.

Ham, the father of Canaan, saw his father naked and told his two brothers outside.

But Shem and Japheth took a garment and laid it across their shoulders; then they walked in backward and covered their father's naked body. Their faces were turned the other way so that they would not see their father naked.

When Noah awoke from his wine and found out what his youngest son had done to him, he said,

"Cursed be Canaan! The lowest of slaves will he be to his brothers."

He also said, "Praise be to the Lord, the God of Shem! May Canaan be the slave of Shem.

May God extend Japheth's territory; may Japheth live in the tents of Shem, and may Canaan be the slave of Japheth."
} 
reward matches the trials to which the woman was subjected: the divine Will gives way to the particular/human will: "Your request is granted"

2.2. The woman's prayer consists of four acts: the first two and the last one are verbal, whereas the third act is nonverbal and ritual (see the table below for the counting of acts).

\begin{tabular}{|c|c|}
\hline Language act * & Type of language act \\
\hline $\begin{array}{l}\text { I.a. Miluiește-mă, } \\
\text { Doamne, ('Lord, [...], } \\
\text { have mercy on me') }\end{array}$ & $\begin{array}{l}\text { - directive speech act in } \\
\text { accordance to the sur- } \\
\text { face structure, realised } \\
\text { directly, and express- } \\
\text { ive from the viewpoint } \\
\text { of the semantic content } \\
\text { conveyed; }\end{array}$ \\
\hline
\end{tabular}

below);
- the vocative case
Doamne ('Lord');

I.b. Fiul lui David! • directly realised speech

('Son of David!') act, structurally pertain-

ing to I.a. (appositive phrase, completing the Interlocutor's identity by referring to/bringing into discourse the name of a famous referent, i.e.David);

I.c. Fiica mea este rău chinuită de demon. ('My daughter is demon-possessed and suffering terribly.')

- expressive speech act
converted to a representative act, indirectly realised;

- expressing the propositional content of the act of request bears the formal markers of an assertion; the exclamative syntax is absent, as is habitual of the kind of expressive act illustrated (act of praying); similarly, causal linkers (which would establish a connection between the given state of affairs and the woman's wish to gain its change) are absent as well;

\section{Markers of illocutionary Pragmatic effect /

force Discursive meaning \\ - verb mood: the hor- - trusting oneself to the tative imperative form almightiness of the Inter- miluieste ('have mercy'); locutor: He has the ca- the verb expresses an ab- pacity to forgive sins $\rightarrow$ stract action which is the faith of the Canaanite reflected in the concrete woman;} action of the other verb in the imperative mood (see below);

Doamne ('Lord');

- vocative case;

- mentioning the "clan"
belonging is indicat-
ive of the capital of
increased trust in the
validity of what is "said"
about the wonders made
by the Saviour $\rightarrow$ faith
expansion;
- the items of informa-
tion provided succes-
sively by the locutor are
now public samples of
her faith, which was re-
inforced as the dialogue
developed;
- lexical-stylistic elements that account for the woman's affectiveparticipative attitude are the possessive adjective mea ('my') and the intensifier rău ('terribly'); 
II. Iar ea, venind, $s-a$ inchinat Lui, zicînd*:

('The woman came and

knelt before him.')

- the actor's assumption of the gesture expressing the preservation of social distance which separates her from the Interlocutor (the Holder of the discursive power);

- the degree of selfdishonouring is directly proportional to the degree of honouring the Other;

III. Doamne, ajută-mă! • see above, I.a.; ('Lord, help me!')
- (see also above, I.a.); the noun in the vocative case Doamne! ('Lord!') and verb in the imperative mood ajută! ('help!'): help me with the present matter: the restoration of my daughter's health;

- the achievement of the action expressed by this second imperative depends on the accomplishment of the action designated by the previous verb: my receiving mercy (i.e., the forgiving of my sins) will lead to my child being healed;

- the woman knows that only her absolution can guarantee her daughter being dispossessed by the devil, as the latter's suffering was not bodily, curable-as in so many other contexts mediated by the Saviour-by means of words, touch, breath or ground, but one that equally altered the mind and soul. The mother is aware of her gift of having given birth, and implicitly, of her unique role and quasi-sacred effect of a mother's prayers for her child.;
- the woman's persistence into faith, her perseverance in the face of an apparent refusal; 


\begin{tabular}{|c|c|}
\hline $\begin{array}{l}\text { IV. Da, Doamne, dar și } \\
\text { cîinii mănîncă din } \\
\text { färîmiturile care cad de } \\
\text { la masa stäpinillor lor. } \\
\text { ('Yes it is, Lord. [...] } \\
\text { Even the dogs eat the } \\
\text { crumbs that fall from } \\
\text { their master's table.') }\end{array}$ & $\begin{array}{l}\text { - expressive speech act } \\
\text { indirectly realised; }\end{array}$ \\
\hline
\end{tabular}

IV. Da, Doamne, darși cîinii mănîncă din färimiturile care cad de la masa stäpininilor lor. 'Yes it is, Lord. [... their master's table.')
- pro-sentence da ('yes');

- noun in the vocative case

Doamne ('Lord');

- adversative linker dar ('but', here even) does not contradict the previous statement ("Yes it is, Lord”), but introduces the rheme by developing the theme: "Even the dogs eat the crumbs that fall from their master's table".
- acceptation (agreement with the Saviour's words) is developed in three stages:

1. "Yes it is, Lord" = selfhumbling;

2.'dogs" (representatives of a kingdom considered inferior to that of humans; the Canaanite woman includes herself in the former) = self-discrediting;

3. acknowledging the masters (superior race, to which she admits the Interlocutor pertains) $=$ meekness.

- "crumbs" = what the masters do not need, things they can spare, redundant things: according to traditional belief, dogs receive food that is qualitatively inferior to that eaten by their human owners; in this case, crumbs are not given to dogs, nor are they thrown to them; they fall $\rightarrow$ the supreme disregard of others (considered from the viewpoint of civilisation or faith) and the absolute lack of mercy towards others.

${ }^{*}$ II is a nonverbal act.

\section{Concluding remarks}

The first two interventions of the woman are actional speech acts, directive only from a lexical-grammatical perspective (prayer imperatives, whose illocutionary aim is to determine the Interlocutor to carry out an action). In fact, they are expressive speech acts (of the prayer subtype), and the verbs a milui ('to have mercy') and a ajuta ('to help') are illocutionary markers whose propositional content describes a human behaviour that professes piety and meekness as specific attitudes. The woman proves to be a skilled user of pragmatic politeness; she employs those types of actions underpinning speech acts (the maxims of tactfulness, consent, modesty and agreement ${ }^{8}$ ) which contribute to the exercise of the appropriate verbal

\footnotetext{
${ }^{8}$ For the success of communication, Grice (1975, apud Moeschler \& Reboul, 1999, p. 188-189) turns to four categories of maxims: maxim of quantity (the locutor's contribution will only contain the necessary information-nothing more, nothing
} 
strategy in view of obtaining an optimal level of politeness and which will eventually lead to the success of the communication.

In announcing the object of her request, the woman simultaneously uses two types of communicative strategies: anticipating strategies (however, without being able to predict how the Interlocutor would react) - the prayers themselves (“Lord, have mercy on me!", "Lord, help me!") and affixal strategies: amplifying certain communicative acts derived from the basic interventions (see above): I.c. = developing interventions I.a. and I.b., which contain the motivation/support (argument) for the information provided in the two preliminary speech acts I.a., I.b..

As previously mentioned, the chosen means of communication are strategically

a) positive, when the woman evokes the Interlocutor's royal ancestry ("Son of David") $\rightarrow$ the manifestation of a strong belief in the special features ensured by His being the perpetuator of the lineage, and

b) negative

$b_{1}$ ) minimising one's person in opposition to augmenting the Saviour's admirable attributes (see acts I.a., III — only He can forgive sins, only He can help—and IV: "Yes it is, Lord." - in which the woman expresses her adherence to the Interlocutor's statements);

$\mathbf{b}_{2}$ ) impersonal and indirect expression of the communicative intention in utterance $\mathbf{I V}$, whose encoding reveals the locutor's ability to correctly decode the "conversational history" encapsulated intertextually in the Saviour's words (the woman's ability to adjust and adapt to the discursive requirements imposed by the Other). Jesus does not "humble" his speech by using explicit signs, but subjects the woman-to offer a demonstration to the others-to an avant la lettre hermeneutic test: "It is not right to take the children's bread and toss it to the dogs.."

The woman's request consists of the following variables (a possible deconstruction of her verbal acts-in the order of their succession-into corresponding semes): meekness + valuing the Intrelocutor + honesty + humbleness + faith + self-discrediting + perseverence. The Saviour's offer/reward is semantically equivalent to absolution.

\section{Bibliography}

\section{A. References}

Bréal, M. \& Bailly, A. (1886). Dictionnaire étimologique latin, Deuxième édition, Librairie Hachette, Paris.

Fillmore, Ch.J. (1977). The Case for Case Reopened, in Syntax and Semantics, Grammatical Relations, vol. 8, nr. 1, Academic Press, New York, San Francisco, London, republished in Fillmore, Ch.J. (2003). Form and Meaning in Language, vol. I, Papers on Semantic Roles, CSLI Publications, Stanford, California, p. 157-199.

Moeschler, J. \& Reboul, A. (1999). Dicționar enciclopedic de pragmatică, coordonarea traducerii Carmen Vlad, Liana Pop, Editura Echinox, Cluj.

Steinhardt, N. (Monahul Nicolae Delarohia) (2006). Dăruind vei dobândi. Cuvinte de credințăa, Editura Mănăstirii Rohia, Rohia.

\section{B. Web sites}

https://www.biblegateway.com/passage/?search=Genesis+9\&version=NIV

https://www.biblegateway.com/passage/?search=Matthew +15 \& version $=$ NIV

https://dexonline.ro/definitie/rug\%C4\%83ciune

https://dexonline.ro/definitie/rug\%C4\%83minte

less); maxim of quality (the locutor's information will be true); maxim of relation (the locutor will be relevant and will not use conversational movements collateral to the topic); maxim of manner (the locutor's expression will be clear and unambiguous). 